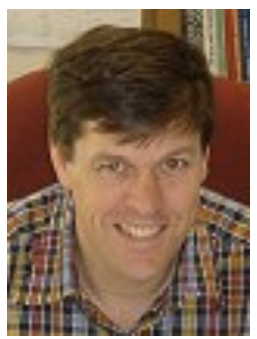

\title{
POISONING THE RIGHT TO WATER IN SOUTH AFRICA: WHAT CAN THE LAW DO?
}

\section{Michael Kidd}

Professor of Law, University of KwaZulu-Natal, Pietermaritzburg, South Africa

\begin{abstract}
This paper examines the major problems currently facing South Africa's water sector and identifies that water shortages will be a significant issue to deal with in the near future. The problem of shortage is exacerbated by severe water quality concerns. The role of the law in addressing these water concerns is examined and it is shown that the law, on paper, is able to address most of these issues and to provide for an integrated water resource management system. Failure to implement the law in the past, however, has led to situations arising that are beyond the power of the law to address and innovative solutions will have to be found. For the future, the law will have to be implemented appropriately in order to avoid similar problems arising again.
\end{abstract}

\section{Introduction}

The availability of water of a quality suitable for its intended use is likely to be a pivotal factor contributing to potential conflict in South Africa. By 'conflict' is meant any disagreement that could lead to anything from debate through litigation to violence. Some conflict (such as debate) is healthy, whereas most people would want to avoid conflict of the type that leads to consequences such as litigation or violence. In the South African context, the following conflicts could arise (and this list is by no means comprehensive): between consumers and water services providers (particularly household users); between users and sectors (for example agriculture, industry, domestic); between South Africa and neighbouring countries; and between existing water rights holders and the government when decisions are made that will impact on those rights. Contributing to the seeds of conflict are the facts that South Africa is water-scarce and the quality of the limited fresh water is increasingly being compromised by pollutants - further exacerbating the scarcity.

There is widespread perception that the state is not doing enough to address these concerns, especially given that water is so central to a prosperous future for the country. This paper examines how the relevant South African law can seek to prevent situations of conflict from occurring and/or address conflict should it arise. In the context of securing provision of adequate water of a suitable quality to users within the new (for South Africa) paradigm of integrated water resources management, this paper identifies gaps in the law and analyses the existing legal tools with a view to assessing how they may assist in meeting the objectives of sustainable management of South Africa's water resources.

\section{Existing Context}

South Africa is largely semi-arid, with average rainfall well below the world average. Whilst groundwater plays an important role in rural water supply, only about one-fifth of groundwater occurs in major aquifer systems that could be utilised on a large scale. ${ }^{1}$ There are approximately 320 major dams with a total capacity of more than 32400 million cubic metres,

\footnotetext{
${ }^{1}$ Department of Water Affairs and Forestry (DWAF), 'National Water Resource Strategy (NWRS)' (2004).
} 
equivalent to 66 per cent of the total mean annual runoff. ${ }^{2}$ In 2004, the National Water Resource Strategy (NWRS) estimated that the total reliable local yield was (for the year 2000) 13227 million cubic metres per annum $\left(\mathrm{m}^{3} / \mathrm{a}\right)$ and the total local requirements 12871 million $\mathrm{m}^{3} / \mathrm{a}$, leaving a positive balance of 186 million $\mathrm{m}^{3} / \mathrm{a}^{3}$ These global figures, however, hide the fact that, of the 19 water management areas (WMAs) in the country (see Figure 1 below), ten were in deficit. The Inkomati area, for example, had a deficit of 258 million $\mathrm{m}^{3} / \mathrm{a}$. More recent (2006) statistics show that only six WMAs are in a surplus situation when taking into account projected demand.

More recently, the Department of Water Affairs (DWA) released the document, Integrated Water Resource Planning for South Africa, ${ }^{4}$ which addresses the water resource situation in each of the 26 priority economic growth areas identified in the National Spatial Development Plan of 2006. The DWA 'has undertaken reconciliation strategy studies for all of the country's major metropolitan areas and some of the large river systems supporting key development zones'. ${ }^{5}$ These water balance reconciliation studies reveal some common themes. First, many of the most important economic growth areas, if not already under conditions of water shortage, will suffer from water shortage in the not-too-distant future. The three main centres are good examples: Gauteng (including Johannesburg and Pretoria amongst other areas), Cape Town and Worcester, and Durban and Pietermaritzburg. Gauteng, even if it successfully implements water conservation/water demand management (WC/WDM) measures reducing demand by 15 per cent, will still suffer shortages by 2014. Additional augmentation of water supply will be required from the Lesotho Highlands Water Project, which will address water supply issues until 2035, but this project is likely only to come on line in 2019. ${ }^{6}$ In Cape Town, without WC/WDM, the system will already be in deficit by 2013. Even with successful implementation of such measures, however, the next augmentation scheme will need to supply water by 2019. ${ }^{7}$ Plans for future supply include new dams, groundwater exploitation, desalination and re-use of water. In the DurbanPietermaritzburg region, a new dam is being planned to provide sufficient water until 2016. The plan is to secure supply until 2023 through re-use of water from several wastewater treatment plants. $^{8}$

The second main trend is that nearly all of the areas need to implement WC/WDM measures in the short-term in order to avoid imminent water stress. Despite these measures, however (as in the Gauteng study above), most areas need augmentation of water supply in the future.

Measures include improving or building new dams, water transfers, increased use of groundwater (where possible), water re-use and desalination in coastal areas.

For the towns not included in the 26 areas mentioned above, the document states that most municipalities do not know their population, nor the quantity of water they are using. This makes it impossible for the municipalities to understand the nature and extent of water losses in their areas. ${ }^{9}$ Moreover, municipalities (in their capacity as Water Services Authorities) often do not recognise that groundwater is suited to small town domestic supply (where it is available); they do not always understand the importance of WC/WDM; and they are 'desperately short of the required funds and skills to address proper water resource management'. ${ }^{10}$

The big picture painted by the information presented above is that water shortage in South Africa is something that is already present and is likely to become more pervasive in future if measures are not taken both to reduce demand (mainly in the short term) and to augment supply

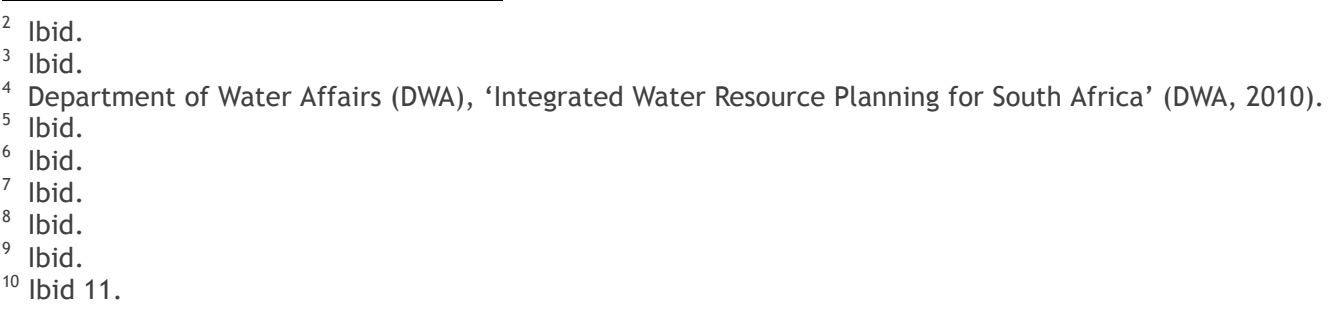


in the medium and longer terms. In addition to current and projected water quantity concerns, South Africa has severe water quality problems throughout the country.

Figure 1: Water Management Areas showing levels of Water Availability ${ }^{11}$

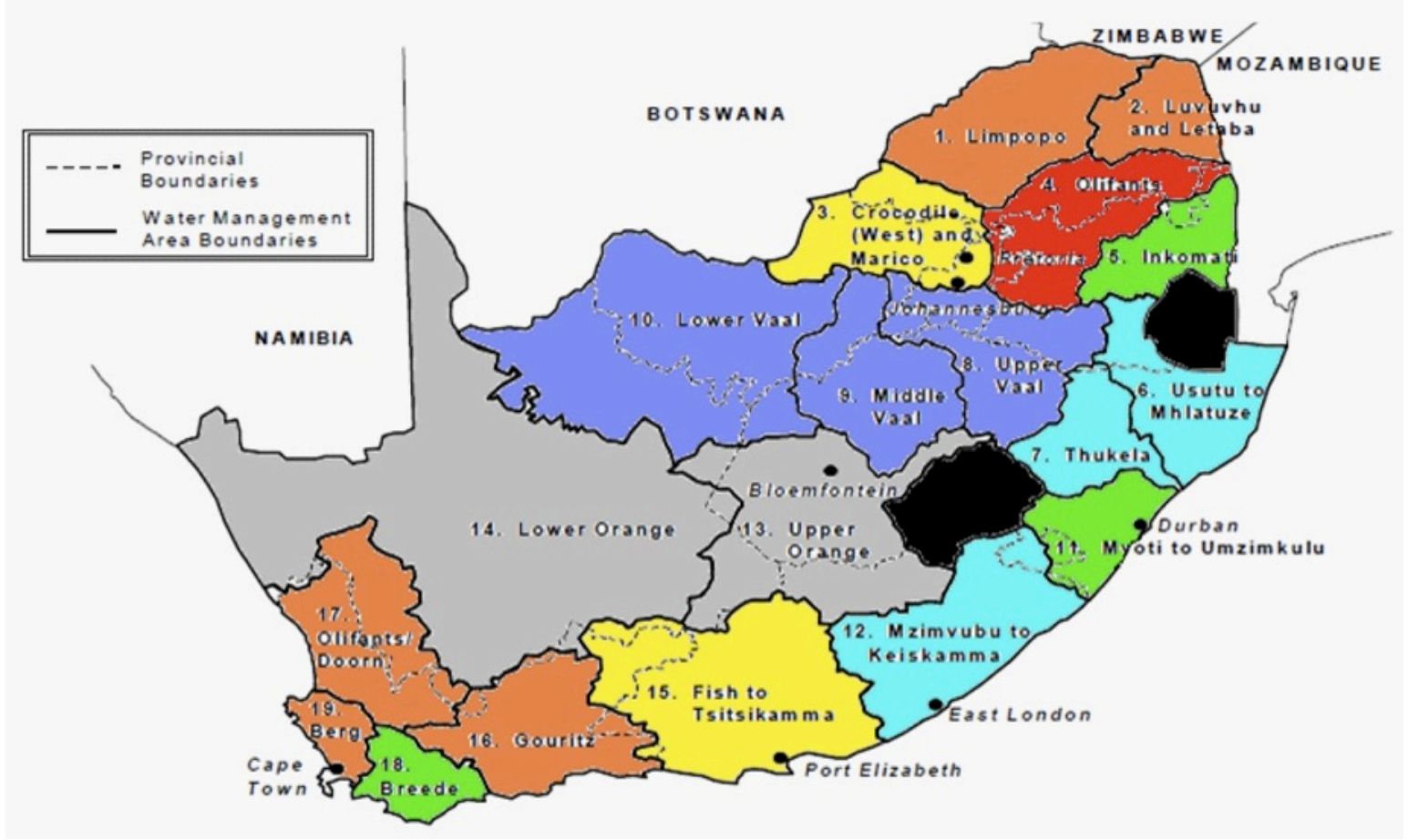

Key:

Entire water management area (WMA) under Water Stress

Majority of component catchments in WMA in deficit

No surplus water available

Some surplus water available from some of the component catchments

Surplus water available from most component catchments

Current surplus but required for projected growth in urban and industrial demand (likely to be fully utilized by 2018)

Current surplus but insufficient for projected growth by 2025

In recent years, there have been numerous reports of water being polluted by sewage from wastewater systems that are not functioning correctly. Recently, the Department of Water Affairs released the Green Drop Report 2009, ${ }^{12}$ which reported on South Africa's waste water quality management performance. The results are alarming. Of the 852 municipal wastewater

\footnotetext{
${ }^{11}$ Water availability for the WMAs derived from Directorate: National Water Resource Planning Water Available for Allocation per Water Management Area (February 2006). Source of original map: DWAF, above n 1.

12 Department of Water Affairs (DWA), 'Green Drop Report 2009' (DWA, 2010).
} 
systems, only 449 (53 per cent) were assessed. The reasons provided in the Report for nonassessment of the other 47 per cent suggest that few, if any, of the municipalities not assessed would have made the grade. Of the 449, 203 municipalities ( 45 per cent) scored better than 50 per cent in the assessment. According to the Report, this indicates that the 'sector is not in complete disrepair', ${ }^{13}$ which is probably cold comfort to most people.

The implications of this widespread failure of management are of great concern. River ecosystems are being poisoned, there is both potential and actual harm being done to agriculture, and those people who have to rely on river water for drinking are being put at risk. ${ }^{14}$ This will be elaborated upon below.

If one drills down into the assessment data and examines the ratings for waste water compliance with licence conditions/general authorisations or special limits, the results are even more a cause for concern. This assessment examines whether the wastewater released into water resources from the treatment works is complying with the relevant legal standards. Only 65 of 449 (14.5 per cent) wastewater systems are in full compliance. Ignoring non-compliance that appears (on my understanding of the assessment criteria) to be formal rather than substantive, ${ }^{15}$ there are still 299 (66.5 per cent) treatment works that are not in substantive compliance with the legal requirements

The result of this widespread failure to properly treat wastewater (primarily domestic wastewater) is that water resources are being filled with harmful pathogens (there have been sporadic outbreaks of cholera in certain areas recently) and nutrients. An overabundance of nutrients leads to eutrophication, which, according to Harding, is 'probably the single greatest threat to water resources' in the country: approximately 35 per cent of impounded water resources in South Africa are seriously impaired (eutrophic to hypertrophic), while a further 20 to 30 per cent are 'incipiently problematical'. All of the major impoundments in Gauteng, 'the economic heartland of the country', are 'grossly impaired'. ${ }^{16}$ In order to combat eutrophication, nutrient loads should be reduced by between 25 to 85 per cent, 'with reductions in excess of $70 \%$ typically required in order to meet desired management targets'. ${ }^{17}$

The other major pollution problem - one that is generating alarm - is acid mine drainage. This is primarily affecting the Witwatersrand (the main goldfields of the country) in Gauteng, the most populous and economically-significant province, and home of Johannesburg and Pretoria. Acid mine drainage (AMD) is:

Potentially the biggest water quality issue in South Africa ... AMD occurs when water collecting in disused mines dissolves minerals in ore seams, and becomes highly acidic as a result. The contaminated water drains back into wetlands and rivers, and can also dissolve limestone, leading to sinkholes. ${ }^{18}$

Although AMD has been around as long as mining has, the problematic extent of the situation became particularly evident in 2002 when AMD decanted (that is, came to the surface) in the Krugersdorp-Randfontein area of the so-called West Rand, not far west of Johannesburg. ${ }^{19}$ Decants typically have $\mathrm{pH}$ levels of less than three, often contain heavy metals and are sometimes radioactive. ${ }^{20}$

\footnotetext{
13 Ibid 4.

14 Jocelyn Newmarch, 'Sewage Treatment “Unacceptable”, Business Day (Johannesburg) 28 April 2010.

${ }^{15}$ By 'formal non-compliance', I am referring to works that have reported incorrectly or made some similar error in providing data, rather than failing to meet the applicable standards, which is what I mean by 'substantive compliance'.

${ }^{16}$ W R Harding, 'Eutrophication of Impounded Water Resources in South Africa: Descent into Crisis' (Paper presented at the WISA Conference, Durban, April 2010).

${ }^{17}$ Ibid 3.

${ }^{18}$ Centre for Development and Enterprise (CDE) Water: A Looming Crisis? (CDE, 2010) 9.

${ }^{19}$ Phil Hobbs and Jude Cobbing, 'The Hydrogeology of the Krugersdorp Game Reserve Area and the Implications for the Management of Mine Water Decant' (Report no. CSIR/NRE/WR/ER/2007/0097/C, CSIR/THRIP, 2007).

${ }^{20}$ E S Van Eeden, M Liefferink and J F Durand, 'Legal Issues Concerning Mine Closure and Social Responsibility on the West Rand' (2009) 5 The Journal for Transdisciplinary Research in Southern Africa 51; Dan Kemp, 'Acid mine water: The
} 
The problem is not confined to the West Rand. In August 2010, it was reported that acid water is currently about $600 \mathrm{~m}$ below Johannesburg's surface, but is rising at a rate of between 0.6 and $0.9 \mathrm{~m}$ per day. ${ }^{21}$ There is also a problem in the Eastern Basin, beneath the town of Nigel (about $50 \mathrm{~km}$ south-east of Johannesburg), and the Loskop Dam near Middelburg in Mpumalanga is also being contaminated. ${ }^{22}$

In setting the context, it remains to consider how South Africa uses its water. According to the NWRS, in 200062 per cent of water was required for agriculture, 23 per cent for urban uses, 4 per cent for rural uses, 6 per cent for mining and bulk industrial uses (outside of urban areas), 2 per cent for power generation (thermal power generation only), and 3 per cent for afforestation. The total amount of water required was 12871 million $\mathrm{m}^{3} / \mathrm{a} .{ }^{23}$

In 1997, it was estimated that 12 to 14 million people did not have access to safe water and over 20 million were without adequate sanitation. ${ }^{24}$ The situation has improved since, but there are still considerable deficits. As of 30 November 2010, just over 86 per cent of all households in South Africa had access to a basic water supply. ${ }^{25}$ This leaves approximately 465000 households with no water infrastructure and relying on unsafe water from dams, springs, etc, or receiving water from vending projects. In July 2005, just over ten per cent of the population had a bucket toilet or no sanitation. ${ }^{26}$ There are numerous water-related diseases associated with use of impure water, often leading to fatalities. ${ }^{27}$ Bald statistics do not tell the whole story, since they do not indicate that the vast majority of the 'have-nots' - when it comes to water and sanitation - are black and poor, which is clearly a legacy of apartheid.

Overall, therefore, South Africa is a water-scarce country, facing projected shortages in the near future which will impact severely on development if demand and supply strategies to address the shortages are not found. This situation is being exacerbated by widespread pollution of water resources, which impedes the country's ability to provide water to all water users, particularly to the millions of people who do not yet have adequate access to water.

The central question for this paper, then, is how the law can assist in meeting the challenges posed by this factual situation.

\section{South African water law: An overview}

An intricate legal framework for water regulation in South Africa is headed by relevant provisions in the Constitution of the Republic of South Africa, 1996. Section 27 provides that everyone has the right to have access to (inter alia) sufficient food and water (s 27(1)(b)). The state is required to take reasonable legislative and other measures, within its available resources, to achieve the progressive realisation of each of the s 27 rights (s $27(2)$ ). The Constitution also sets out the respective 'functional areas of legislative (and consequently administrative) compe-

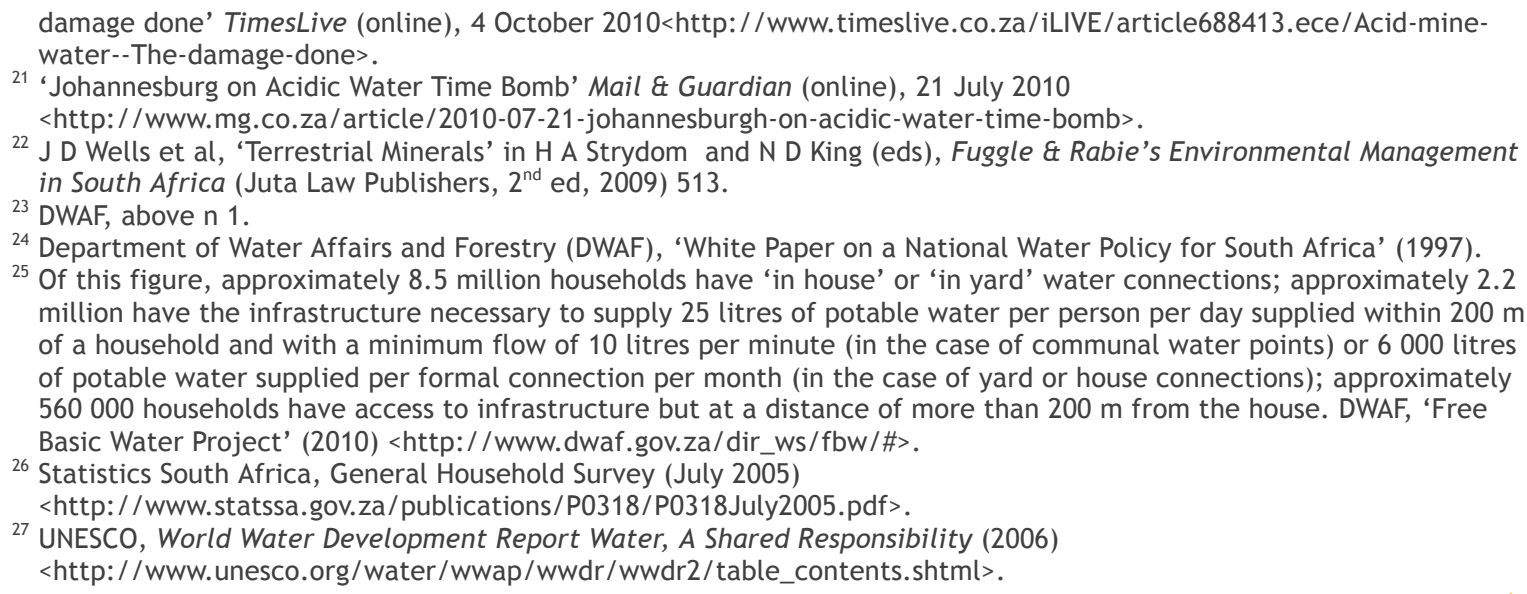

${ }^{24}$ Department of Water Affairs and Forestry (DWAF), 'White Paper on a National Water Policy for South Africa' (1997).

${ }^{25}$ Of this figure, approximately 8.5 million households have 'in house' or 'in yard' water connections; approximately 2.2 million have the infrastructure necessary to supply 25 litres of potable water per person per day supplied within $200 \mathrm{~m}$ of a household and with a minimum flow of 10 litres per minute (in the case of communal water points) or 6000 litres of potable water supplied per formal connection per month (in the case of yard or house connections); approximately 560000 households have access to infrastructure but at a distance of more than $200 \mathrm{~m}$ from the house. DWAF, 'Free Basic Water Project' (2010) <http://www.dwaf.gov.za/dir_ws/fbw/\#>.

${ }^{26}$ Statistics South Africa, General Household Survey (July 2005) <http://www.statssa.gov.za/publications/P0318/P0318July2005.pdf>.

27 UNESCO, World Water Development Report Water, A Shared Responsibility (2006) <http://www.unesco.org/water/wwap/wwdr/wwdr2/table_contents.shtml>. 
tence' between national and provincial government, and water is reserved for the national sphere.

The primary legislation regulating management of water resources is the National Water Act 1998 ('NWA'). Regulating the provision of water and sanitation services to inhabitants of the country is the Water Services Act 1997 ('WSA'). Importantly, the NWA recognises in its preamble that water is part of a unitary, interdependent cycle. Management of water is premised on the principle that the national government is the public trustee of the country's water resources and is thus tasked with ensuring that water 'is protected, used, developed, conserved, managed and controlled in a sustainable and equitable manner, for the benefit of all persons and in accordance with its constitutional mandate' ${ }^{28}$ The Minister is 'ultimately responsible to ensure that water is allocated equitably and used beneficially in the public interest, while promoting environmental values' (s 3(2)), and 'has the power to regulate the use, flow and control of all water in the Republic' (s 3(3)). The Act revolves around this principle.

Bearing this principle in mind, let us start with a broad overview of the regulatory framework in the NWA. The Act requires the drawing up of an overarching strategy. ${ }^{29}$ More specific planning decisions dealing with the nation's water resources have to comply with the NWRS. These decisions include the classification of water resources (NWA ch 3 pts 1 and 2) (essentially into polluted, lesser polluted and most polluted categories) and the determination of resource quality objectives (ch 3 pt 2). These decisions are followed by determination of the Reserve (ch 3 pt 3), discussed in more detail later in this paper. This is a central concept in water management as it provides for priority water-use in order to meet basic human needs and to protect the (aquatic) environment. Water will be allocated first to the Reserve and whatever is left will be available for allocation to other users, subject to water use licences (subject to certain exceptions). ${ }^{30}$ The remainder of the Act, in essence, provides for management/governance structures and devices (for example, provision for water use charges) and for protection of water resources. In overview, the structure is relatively simple, but in reality it is probably fair to describe it as a legal minefield.

The WSA, as its name suggests, provides for the provision of water services to consumers, with particular emphasis on domestic users. Much of the Act revolves around the institutional arrangements for the provision of such services, and the powers and duties of the water services providers. Water services as envisaged in the WSA are primarily the responsibility of local government.

Instead of detailing the legal provisions here, some of the complexity will be revealed as the various water management issues are discussed below.

\section{Addressing the 'water crisis'}

In order to evaluate the role that law can play in addressing the problems outlined above, it is necessary to outline, as far as possible, the underlying causes of the problems. For purposes of this paper, it will be convenient to examine the major issues in four categories:

i) Current and/or future water shortage;

ii) Water contamination through failure to treat waste water;

iii) Acid mine drainage;

iv) Provision of basic water for human vitality.

A factor that feeds into all four categories is inadequate leadership in water management. This is a problem from the very top down to those responsible for running wastewater treatment

\footnotetext{
${ }^{28}$ National Water Act 1998 (NWA) (South Africa), s 3(1)).

${ }^{29}$ NWRS, above n 1 , ss 5-7.

${ }^{30}$ National Water Act 1998, ch 4.
} 
plants. It is probably fair to say that the water portfolio at cabinet level is not one of the 'heavy hitters', ${ }^{31}$ and water has to find a louder voice at this level. At more operational levels, there are serious skills shortages. Commentators suggest that, whereas in the 1990 s there were 3000 to 4000 engineers in the water sector, that number has now dwindled to about $1400 .{ }^{32}$ There are various reasons for this, but ultimately the means of addressing this probably exist in the realms of political decision-making rather than law. Improved political leadership is, however, a prerequisite for effective use of the legal tools that are available to address the water crisis.

\title{
Current and/or future water shortages
}

It is inescapable that much of South Africa is arid or semi-arid. In that light, authorities need to consider the suitability of water use in various parts of the country, particularly for agriculture. In addition, wastage is a problem that needs urgent attention.

\section{Suitability of agricultural water use}

South Africa's well-developed infrastructure (including numerous dams and inter-basin transfer schemes) allows South Africa to have a per capita storage level 'considerably higher' than in any other African country. ${ }^{33}$ As a result, South Africa has been able to 'maintain highly water dependent marginal economic activities such as irrigation agriculture through dry periods' ${ }^{34}$ While this appears, at first glance, to be admirable, it may well be that water used in such activities could be more beneficially used elsewhere. In this context, the concept of 'virtual water' ought to be a central consideration. The concept was introduced by Allan who defined it as the water embodied in food crops that are traded internationally. ${ }^{35}$ For example, if 1000 tonnes of water are required to grow one tonne of wheat, the virtual water value of wheat would be 1000 tonnes. The concept was developed within the context of food security, but it is also relevant to the management and conservation of water resources. It has been observed that

\begin{abstract}
Essentially, the concept encourages a country to view agricultural crops in terms of the amount of water required to produce those crops. In this way, a country wishing to enhance food security and at the same time minimize impacts on its water resource, may opt to import crops from another country instead of producing the crops itself, and thus avoid the associated impacts of water use. Such virtual water considerations assist in the tough tradeoffs between water resource protection and food security. Improved trade-offs of this kind can lead to better informed trade policies that a) improve food security, and b) ensure that scarce water resources are adequately protected as well as used to their optimal benefit. ${ }^{36}$
\end{abstract}

Historically, it was important that South Africa produced most of its own food due to trade sanctions in the apartheid era. That imperative is no longer relevant and it may well be that authorities must take hard decisions as to the suitability of many agricultural practices in the country. Sixty-two per cent of South Africa's water is used for irrigation, ${ }^{37}$ so the main focus would be on irrigation agriculture, but rain-fed agriculture's negative impacts on water resources (fertilizer and pesticide run-off, for example) may well dictate that importation of certain products should replace production of rain-fed agricultural produce. This obviously requires careful research, but the relevant question for present purposes is the role that the law can play in this.

\footnotetext{
${ }^{31}$ This is the case, too, with environment - in fact, the two portfolios are now combined in one ministry.

${ }^{32} \mathrm{CDE}$, above $\mathrm{n} 18$.

${ }^{33}$ N A King, G Maree and A Muir 'Freshwater Systems' in HA Strydom \& ND King (eds), Fuggle \& Rabie's Environmental Management in South Africa (Juta Law Publishers, $2^{\text {nd }}$ ed, 2009) 435.

${ }^{34}$ Ibid 435.

35 J A Allan, 'Virtual Water: A Strategic Resource, Global Solutions to Regional Deficits' (1998) 36 Groundwater 545.

36 J M Dabrowski, K Murray, P J Ashton and J J Leaner 'Agricultural Impacts on Water Quality and implications for Virtual Water Trading Decisions’ (2009) 68 Ecological Economics 1074, 1074-5.

${ }^{37}$ DWAF, above $\mathrm{n} 1$.
} 
Farmers using water require a water use licence under the terms of the NWA (s 22). In order to ease the transition from the old legal regime (under the Water Act 54 of 1956) and the new one introduced in 1998, the NWA provides for an exception to the requirement of a licence in the case of 'a continuation of an existing lawful use', essentially any lawful use which took place at any time during a period of two years immediately before the date of commencement of the Act. Most farmers would still, in 2010, be using water on the basis of use rights that existed when the NWA commenced in 1999. A person, or his/her successor-in-title, may continue with an existing lawful water use, subject to, inter alia, its replacement by a licence in terms of the NWA (s 34(1)). The Act does envisage circumstances where a person with an existing lawful use may be required to apply for a licence: if it is desirable that water use in respect of one or more water resources within a specific geographic area be licensed, either to achieve a fair allocation of water from a water resource which is under water stress or when it is necessary to review prevailing water use to achieve equity in allocations; or to promote beneficial use of water in the public interest; or to facilitate efficient management of the water resource; or to protect water resource quality. If any of these conditions exists, the responsible authority may issue a notice requiring persons to apply for licences for one or more types of water use contemplated in s 21 of the NWA (s 43(1)).

Use of these provisions could, therefore, reduce (or completely remove) existing allocations in water-stressed areas. This would obviously have political ramifications, but the political voice of (mostly white) farmers in South Africa is considerably less important than it was in the apartheid era.

Nevertheless, there could be a more palatable approach, particularly in areas where there are shortages less serious than a situation of water stress. Currently, users do not pay for most water for irrigation, although it is subject to specific allocations. The Act does provide for the imposition of water use charges for various purposes including the reduction of waste of water, so these provisions could be used to persuade users to use water more efficiently, as there are undoubtedly often inefficient irrigation practices.

An important question that arises in the context of decisions that would lead to the reduction or removal of water rights is whether the rights holder would be entitled to compensation. The NWA does provide for compensation in s 22 , and s 25 of the Constitution provides for compensation when property rights are expropriated. A person suffering from reduction (or removal) of existing water use rights would not, however, be entitled to compensation, since expropriation of property rights attracts compensation only in cases where all of the rights in property are expropriated,$^{38}$ and existing water use rights are attached to the land. In other words, existing water use rights are part of a bundle of rights attaching to the property in question and not self-standing property rights in their own right.

\section{Water conservation and water demand management (WC/WDM)}

Water conservation and water demand management (WC/WDM) is a central theme in the DWA's Integrated Water Resource Planning for South Africa. ${ }^{39}$ Authorities are already pursuing WC/WDM efforts in many of the major urban centres, but implementation is currently problematic in many smaller towns because of insufficient information relating to current usage and consequently the amount of water being wasted.

There are several provisions directly relevant to WC/WDM in the WSA. First, conditions for the supply of water services must contain, inter alia, provision for measures to promote WC/WDM (WSA s $4(2)(\mathrm{c})(\mathrm{vi}))$. Every water services authority (a municipality) ${ }^{40}$ has a duty to all consumers

\footnotetext{
${ }^{38}$ Harksen v Lane NO [1998] 1 SA 300 paras 29-39 (Constitutional Court).

${ }^{39}$ DWA, Integrated Water Resource Planning, above $\mathrm{n} 4$.

${ }^{40}$ Water services authorities are defined as any municipality responsible for ensuring access to water services (WSA s 1). These are generally district municipalities.
} 
or potential consumers in its area of jurisdiction to progressively ensure efficient, affordable, economical and sustainable access to water services (WSA s 11(1)), subject to, inter alia, the duty to conserve water resources (WSA s 11(2)(e)). In addition, every water services authority must, within a year of commencement of the Act, prepare a draft water services development plan for its area of jurisdiction, and a summary of that plan. The draft plan must contain details, inter alia, of: the physical attributes of the area to which it applies; the size and distribution of the population within that area; existing water services; and existing and proposed water conservation, recycling and environmental protection measures (WSA s 13). Every water services authority must also make by-laws which contain conditions for the provision of water services, and which must provide for at least, inter alia, the prevention of unlawful connections to water services works and the unlawful or wasteful use of water (WSA s 21(1)(g)). Section 82 of the Act provides for the offence of continuing the wasteful use of water after being called upon to stop by an authority.

This description of the WSA requirements shows that those municipalities described above as not being able to implement WC/WDM because of lack of knowledge of the population and quantity of water being used, have evidently not drawn up the plans that they are required to prepare in terms of the WSA.

The Act empowers the Minister to prescribe compulsory national standards relating to, inter alia, the provision of water services; the effective and sustainable use of water resources for water services; and the nature, operation, sustainability, operational efficiency and economic viability of water services (WSA s 9(1)). In prescribing such standards, the Minister must consider, inter alia: the operational efficiency and economic viability of water services; any impact which the water services might have on the environment; and the obligations of the National Government as custodian of water resources (WSA s 9(3)). Every water services institution must comply with these standards (WSA s 9(4)).

In short, there is ample provision in the WSA for the implementation of WC/WDM, and it could be compellingly argued that water services authorities are required to implement such measures. The first step in ensuring WC/WDM, then, would be to ensure that water services authorities do what is required of them in terms of the existing law. I will return to this issue shortly. Moreover, there is merit in the view that the Minister ought to use her powers in terms of $\mathrm{s} 9$ of the WSA to prescribe norms and/or standards for WC/WDM in municipalities throughout the country. Although s 9 does not contain explicit reference to the terms 'water conservation' or 'demand', requirements of 'sustainability', 'efficiency' and 'economic viability', and consideration of the environment together cover notions of conservation of water.

As for municipalities (acting as water services authorities) doing what is required of them in terms of legislation, this is easier said than done. In many areas, municipalities are failing to fulfil their statutory duties and responsibilities, not only in the water services sphere. An important Constitutional concept is co-operative government, which in essence requires organs of state to resolve conflicts between each other in a non-adversarial manner (Constitution, $\mathrm{s}$ 41(1)(h)). This would prevent, for example, the national Department of Water Affairs from bringing a court application requiring a municipality to comply with its statutory duties in respect of water services. Whereas co-operative governance is aimed at avoiding intra-governmental litigation, experience suggests that the concept has led to government departments adopting a 'hands off' policy; conflict is not resolved at all.

Yet the Constitution also clearly provides for the power of provincial government to interfere in municipalities if the latter are not carrying out their statutory duties (Constitution s 139). The provincial executive may, for example, issue a directive indicating to the municipality what it must do in order to meet its obligations. However, there have been no instances of this power having been used in respect of the pervasive failure of municipalities to meet their obligations in 
terms of the Water Services Act. Despite this not having been done, this is an option that should be seriously considered.

Another option is for members of 'civil society' to seek mandatory interdicts requesting courts to order the municipalities to carry out their statutory duties, but the pervasive nature of the noncompliance means that, even if there are applicants prepared to embark on litigation, the result would not be comprehensive.

Overall, the problems observed here revolve around lack of political will and, until this is addressed, there is not much prospect of significant progress in relation to WC/WDM across the board rather than only in certain, bigger centres.

\section{Water contamination through failure to treat wastewater}

One of the main objects of the WSA is to provide for the right of access to basic water supply and the right to basic sanitation necessary to secure sufficient water and an environment not harmful to human health or wellbeing (WSA s 2(a)). 'Basic sanitation' means the prescribed minimum standard of services necessary for the safe, hygienic and adequate collection, removal, disposal or purification of human excreta, domestic wastewater and sewage from households, including informal households (WSA s 1). 'Sanitation services' means the collection, removal, disposal or purification of human excreta, domestic wastewater, sewage and effluent resulting from the use of water for commercial purposes (WSA s 1). Water services authorities are under a duty to all consumers or potential consumers in their areas of jurisdiction to progressively ensure efficient, affordable, economical and sustainable access to water services (which includes sanitation services) (WSA s 11). They may engage water services providers to provide such services or may act as water services providers themselves (WSA s 19).

If they are working properly, water treatment works release purified effluent into water resources. The release of wastewater is a 'water use' in terms of the NWA and thus requires a licence (NWA s 22), which would specify the standards that the released treated water must meet. ${ }^{41}$ In many cases, as indicated in the Green Drop Report, ${ }^{42}$ these standards are not being met. This means that untreated or insufficiently treated effluent is ending up in the country's watercourses. An additional problem is that, even if treatment works are in compliance with the relevant standards, the standards are so-called uniform effluent standards so they do not take into account the cumulative effect of discharge of numbers of separate effluent streams into a water resource, which is often a cause of excessive nutrient loading.

The causes of the pervasive failure of water services institutions to treat sewage properly are not necessarily easy to pinpoint. It is tempting for many critics of the current government to point fingers and claim that municipalities are simply not doing their jobs. This is not untrue, but it is over-simplistic. As noted above, there is a severe shortage of skilled (and often also unskilled) treatment works operators in the system. In addition to the skills shortage, the current government has also been unfairly criticised for problems that were inherited from the past regime. If anything, the criticism should be that the current government failed to appreciate the extent of the problem and consequently failed to take appropriate steps, but the current government certainly did not cause the problem. Historically, provision of water services infrastructure was prioritised for the minority white population and their residential (and business) areas, whereas the black residential areas were not adequately serviced. This state of affairs was certainly perpetuated by the post-1948 apartheid government, but it had its roots far

\footnotetext{
${ }^{41}$ In terms of NWA s 21, which lists the water uses, one of the water uses is 'discharging waste or water containing waste into a water resource through a pipe, canal, sewer, sea outfall or other conduit'. If the treatment works is discharging less than $200 \mathrm{~m}^{3}$ of water per day, then it is subject to a general authorisation in terms of $\mathrm{s} 39$ of the NWA, which discharges the user from the requirement of a licence. Operating in terms of a general authorisation requires compliance with standards in any event.

${ }^{42}$ DWA, Green Drop Report, above n 12.
} 
earlier. ${ }^{43}$ The new government in 1994 thus inherited a legacy that could be characterized as follows:

Previously the country's water infrastructure had focused primarily on a population of about 6 million (comparatively affluent) whites, some people of colour in segregated urban townships, and on meeting the needs of the highly productive (and lucrative) industrial and agricultural sectors. The same infrastructure, after 1994, had to make provision for a population of more than 42 million people, of whom many were now living in informal settlements on the fringes of the country's urban areas. Needless to say the existing infrastructure was simply inadequate. ${ }^{44}$

Rapid housing development under the new government coupled with increased urbanization has exacerbated the situation, since the water infrastructure has not kept pace with other development. ${ }^{45}$ It would appear, in addition, that much of the existing infrastructure has not been adequately maintained, which has further compounded the problem. It will apparently cost R500 billion to address backlogs in sanitation services and to repair and increase the capacity of infrastructure, 30 to 40 per cent of which is not working. ${ }^{46}$

This shows that, even though municipalities are not complying with the WSA and also probably falling afoul of the prohibition on water pollution in $\mathrm{s}$ 151(1)(i) of the NWA, the problem will not be addressed simply by exhorting municipalities to do what the law requires. If their physical infrastructure does not allow this, there will have to be considerable expenditure to remedy the situation. To a certain extent, municipalities are at fault since they have been approving budgets for 15 years without providing adequately for water services infrastructure. Part of the problem, in my view, is that water pollution problems are not immediately evident to average consumers (the electorate), unlike the failure of the electricity supply system. If sanitation failures manifested themselves in households being unable to flush their waste, expenditure on sanitation would be prioritised.

It may help for the Minister to use her powers in terms of $\mathrm{s} 9$ of the NWA to mandate norms and standards for water treatment works, both in terms of capacity (determined by the population in a municipality's jurisdiction connected to sanitation) and mandatory levels of maintenance. It would probably also be prudent to provide for minimum qualifications for managers of water treatment works, although this would be problematic if demand exceeded supply of appropriately qualified personnel. This, at least, is something that should be researched, as should the financial ramifications of such suggestions.

Unfortunately, the scale of the problem has reached such magnitude that it is surely beyond the ability (financial and expertise) of municipalities to solve acting by themselves. The time has come for the Minister to exercise her responsibility as the trustee of the nation's water resources to compel municipalities to take what steps they are able to whilst simultaneously putting in place measures to address those aspects of the problem that are beyond municipalities' capabilities (securing appropriate finance, for example).

\section{Acid mine drainage}

It appears that the majority of the AMD problem in South Africa emanates from mines that are no longer in use. This highlights the issue of post-closure management of mines. If it is not possible for the owners to rehabilitate and walk away leaving benign mine workings, then ongoing management (such as pumping water out of disused mines and treating that water if it is polluted) is necessary. The polluter pays principle, an overarching principle of South African law in terms of s 2(4)(p) of the National Environmental Management Act 107 of 1998 (NEMA), requires

\footnotetext{
43 Johann W N Tempelhoff, 'Civil Society and Sanitation Hydropolitics: A Case Study of South Africa's Vaal River Barrage' (2009) 34 Physics and Chemistry of the Earth 164.

44 Ibid 165.

${ }^{45}$ Ibid.

${ }^{46} \mathrm{CDE}$, above $\mathrm{n} 18$.
} 
that the owners ought to pay for this ongoing management. It should be a cost that is built into the financial planning and decision-making as to the likely profitability of the mine. This observation is well and good if one were talking about how to deal with the problem arising in the future, but there are some problems with its applicability in respect of past mining practices.

The AMD problem is sufficiently serious that it has transcended the Department of Water Affairs and has landed on the table of the Cabinet. An inter-ministerial committee was established to examine the problem and consider how to address it, and it reported early in 2011. The recommendations of the committee are essentially 'band-aid' type measures that are far short of permanent solutions: pumping and treatment of acid water, but leaving residue that will cause problems of excessive salinity. ${ }^{47}$ The Committee's initial mandate stated that South Africa has strengthened its environmental regulation over the past 15 years, in accordance with international best practice. South African law includes 'the provision for mine closure management plans as a pre-requisite for the granting of future mining licences. In addition mine closure management plans make provision for rehabilitation measures'. ${ }^{48}$ The recommendations, however, essentially put the applicable legal mechanisms on the 'back-burner'. The report is aimed primarily at dealing with the physical problem of AMD in the short-term, but issues of legal liability have been recognised as something requiring immediate 'research'. It would appear that legal solutions are not being pursued at present for a variety of reasons: a concern that 'legal wrangling' will delay addressing the physical problem; as well as the problems of visiting financial liability on 'derelict and ownerless' mines. It seems that the approach is to address the physical AMD problem first (as a matter of some urgency) and then pursue legal avenues (as far as possible) once that has been done.

What role can the law play in this regard? The inter-ministerial response correctly observes that there are provisions in our minerals legislation providing for management of the environment during mining operations, including the duty to remedy damage and rehabilitate (s 38(1) of the Mineral and Petroleum Resources Development Act 28 of 2002 (MPRDA)), mine closures (MPRDA s 43 ), and the provision of security before mining operations commence in order to cover future rehabilitation costs (MPRDA s 41). In addition, the Act explicitly deals with the remediation of environmental damage: $\mathrm{s} 45$ is entitled 'Minister's power to recover costs in event of urgent remedial measures' and provides for the Minister to direct the mineral rights holder to take certain measures to address environmental damage or pollution. This is in addition to the general polluter-pays principle in NEMA, mentioned above. If the person in question fails to comply, then the Minister may take the measures in question. The Minister may fund these measures by making an ex parte application to a High Court for an order to seize and sell such property of the holder as may be necessary to cover the expenses of implementing such measures. In the event that such funds do not cover the expenses, the Minister may use funds appropriated for that purpose by Parliament.

The Act also deals with the remediation of environmental damage where a rights holder no longer exists or cannot be traced. In such a case, the Minister may instruct the Regional Manager concerned to take the necessary measures to prevent further pollution or degradation, or to make the area safe (MPRDA s 46). These measures will be funded from the financial provision (security) provided by the rights holder in question, any shortfall from money appropriated from Parliament.

There are thus clearly legal provisions that deal (on paper) with the current situation in respect of AMD. Financial provision was required by earlier minerals legislation as well, but anecdotal evidence suggests that this has often been laughably inadequate for its intended purposes. Although recovery of the costs of remediation is not confined to the financial provision, if the mine

\footnotetext{
${ }^{47}$ Report to the Inter-Ministerial Committee on Acid Mine Drainage (2010) <http://www.dwaf.gov.za/Documents/ACIDReport.pdf>.

${ }^{48}$ Buyelwa Sonjica, 'Statement on the Inter-ministerial Committee on AMD' (Press Release, 6 September 2010) <http://www.info.gov.za/speech/DynamicAction?pageid+461\&sid=12762\&tid=17384>.
} 
is now 'ownerless' the possibility of recovering costs over and above the financial provision is absent. Many of the derelict mines that are the source of the current AMD problem are now without owners.

There are other provisions, such as s 19 in the NWA (dealing with the prevention and remediation of pollution) and $\mathrm{s} 28$ of the NEMA (dealing with a duty of care in respect of the environment and remediation of environmental damage) that could potentially be used in such circumstances too. In essence, both provide for the person who caused the pollution or owner of the land to take remedial measures, failing which the relevant authority is empowered to take the necessary steps and recover the costs from the person concerned.

Even if the seemingly obvious legal remedies are brought into play in the future, the prospect of the costs of remediation being met in full by the proceeds of legal liability are not good because of the sheer scale of the problem and the likely difficulties in apportioning the liability due to the many ownerless mines involved in the problem.

As for the future, it is clear that adequate provision must be made for environmental management measures from cradle to grave. Insofar as it appears that the problems of AMD cannot be rehabilitated in the sense that they can be permanently 'capped', provision must be made for the indefinite future pumping of water and whatever other measures are necessary to avoid the problem. If this results in the mine being uneconomical, then mining should not take place. This is in accordance with the notion of sustainable development and many of the associated environmental management principles that underpin our law (NEMA s 2). That may be an unpalatable pill for the powers-that-be to swallow, but there cannot be any other way if the environment is to be utilized in a sustainable way.

\section{Provision of basic water for human vitality}

The issues relating to provision of basic water for all persons in the country are such that they warrant a paper (or possibly a book) in themselves. There are still millions of people in South Africa who do not have adequate access to water. Even those who are classified as having access to water in many cases do not have piped water in their dwellings. This issue is not only a problem in respect of persons who have never been provided with water services, but also for numerous poor people with water services who are unable to pay for such services.

The WSA does provide for water services providers to charge for water services. In the context of the Constitutional right to water (s 27), however, the government has a programme whereby indigent persons are provided with 'free basic water' - an amount that provides for the minimum necessary for drinking, sanitation and washing without any charge to the consumer.

Section 9 of the WSA empowers the Minister to prescribe compulsory national standards relating to the provision of water services, amongst other related matters. Every water services institution is required to comply with such standards. The Minister of Water Affairs has prescribed standards in a notice entitled 'Regulations relating to compulsory national standards and measures to conserve water' (RSA, 2001). ${ }^{49}$ Regulation 3 provides that the minimum standard for basic water supply is:

a) the provision of appropriate education in respect of effective water use; and

b) a minimum quantity of potable water of 25 litres per person per day or 6 kilolitres per household per month -

i) at a minimum flow rate of not less than 10 litres per minute;

ii) within 200 metres of a household; and

iii) with an effectiveness such that no consumer is without a supply for more than seven full days in any year'.

\footnotetext{
49 'Regulations Relating to Compulsory National Standards and Measures to Conserve Water' (South Africa) in GN R509 GG 22355, 8 June 2001.
} 
If the water supply is interrupted, reg 4 provides that the water services institution must take steps to ensure that, where water services are interrupted for a period of more than 24 hours for reasons other than those contemplated in $\mathrm{s} 4$ of the Act, a consumer has access to alternative water services comprising at least 10 litres of potable water per person per day and sanitation services sufficient to protect health. The provision of water is governed not only by the WSA, but also by municipal by-laws.

The Act and regulations do not provide for basic water supply to be free, but many municipalities provide a certain amount of water to consumers free, charging rising tariffs above the free basic water level at an appropriate level to underwrite the free water provision.

Since s 27 of the Constitution contains an internal modifier providing for the progressive realization of the right to water, it is not envisaged that everyone will immediately have a claim to have the right realised - the Constitution recognises that it is not feasible to meet such socioeconomic rights overnight and that the government will have to roll out the services in a reasonable way and within a reasonable time.

The provision of water services costs money, and the cost of such provision is usually passed onto consumers. During the apartheid era, one of the methods of resistance to the authorities was a refusal by many people to pay for services (water and electricity) and this practice survived, to a certain extent, into the post-apartheid era. Many municipalities (particularly the bigger ones) are becoming increasingly concerned about meeting the costs of service provision and it is this aspect that has given rise to some conflict. In the case of Mazibuko v City of Johannesburg, ${ }^{50}$ the city installed pre-payment meters in certain areas of the city, including Phiri township, a very poor part of Soweto. The case involved numerous legal issues, many of which were clearly complex seeing as there were three different decisions - the High Court, the Supreme Court of Appeal and the Constitutional Court. For present purposes, one of the main complaints of the Phiri dwellers was that the free basic water allocation ( 25 litres per person per day) was not enough and that the pre-payment meters had the effect of depriving them of water for a significant part of the month once the free basic allocation had been exhausted.

The Constitutional Court, which had the final word in the matter, refused to declare a specific amount of water to be a minimum for purposes of meeting the $s 27$ Constitutional right to water, and held that the installation of the prepayment meters was valid. Not surprisingly, this decision has led to mixed responses, with many people labelling it (justifiably, in my opinion) as antipoor. Full discussion of this judgment is beyond the scope of this paper but some observations in the context of the focus of this paper are worthwhile.

The case clearly illustrates that fulfilment by water services providers of the Constitutional right to water, whilst simultaneously securing payment for water services, is no easy task. This is particularly true in respect of those who are unable to pay for water services. Even so, one of the disturbing aspects of the Mazibuko judgment was that the issue was presented to the Court as a simple choice between a bureaucratically unworkable system where individual circumstances would be taken into account as against a one-size-fits-all system where, unfortunately, poor people would fall through the cracks. It would appear that this is overly simplistic and that there are many other possible choices, but the Court uncritically followed the city's line that its approach was the only one possible.

The Court also ignored the fact that pre-payment meters have been declared illegal in other jurisdictions precisely because of the fact that the poor are deprived of water once their credit runs out, leading to disease. ${ }^{51}$ The notorious cholera outbreak in the Uthungulu district between 2000 and 2002 was largely due to the conversion of free communal taps to pre-paid meters. ${ }^{52}$

\footnotetext{
${ }^{50}$ [2010] 4 SA 1 (Constitutional Court).

${ }^{51}$ Damon Barrett and Vinodh Jaichand, 'The Right to Water, Privatised Water and Access to Justice: Tackling United Kingdom Water Companies' Practices in Developing Countries' (2007) 23 South African Journal of Human Rights 543. ${ }^{52}$ Ibid.
} 
The link between pre-paid meters and disease (in this case dysentery) has also been observed in the United Kingdom, where disconnection for non-payment and any sort of water supply limiting devices have been made illegal by s 1 of the Water Industry Act $1999 .{ }^{53}$ The British government stated in 1998 that:

[Where] the water supply is disconnected the maintenance of good health and hygiene can only be put at risk. In light of this and having considered the available evidence, the Government believes that disconnection does not have to be an integral part of the process of collecting arrears of charges for water supplied to domestic premises. ${ }^{54}$

If one accepts the view that the exhaustion of pre-paid credit amounts to disconnection, this view ought to prevail in South Africa as well.

The South Africa Constitution does not contain only a right to water, but also (amongst many others) the right to human dignity: Everyone has inherent dignity and the right to have their dignity respected and protected (Constitution s 10). Access to a basic water supply is not only something that is relevant in the context of human vitality (water being the basis of health and life), but is also a central component of human dignity. In this light, the fact that there is not one mention of dignity in the Mazibuko judgment beggars belief.

The South African government faces considerable challenges in providing water services to everyone, not the least of which is payment for those services. A far more nuanced view by the water services authorities than that displayed by the City of Johannesburg in Mazibuko is necessary to balance the conflicting imperatives in this context.

\section{A cross-cutting issue: ensuring water for the environment}

In the brief overview of the National Water Act earlier in the paper, the centrality of the concept of the 'Reserve' was mentioned. The 'Reserve' is defined (NWA s 1) as:

[T] he quantity and quality of water required -

(a) to satisfy basic human needs by securing a basic water supply, as prescribed under the WSA, for people who are now or who will, in the reasonably near future, be -

i) relying upon;

ii) taking water from; or

iii) being supplied from,

the relevant water resource; and

(b) to protect aquatic ecosystems in order to secure ecologically sustainable development and use of the relevant water resource.

The human needs aspect of the Reserve was discussed in the previous section. The second aspect - ensuring sufficient water (in quantity and quality) for the protection of aquatic ecosystems has been hailed as a particularly innovative aspect of the Act. It is, however, an aspect of the Act that has not yet been properly implemented, if it can be said to have been implemented at all.

The NWRS took the approach that:

[C] ] cent of the total river flow is required as ecological Reserve, which needs to remain in the rivers to maintain a healthy biophysical environment. This proportion,

\footnotetext{
${ }^{53}$ Ibid.

${ }^{54}$ Ibid 551.
} 
however, varies greatly across the country, from about 12 per cent in the drier parts to around 30 per cent in the wetter areas. ${ }^{55}$

These provisional assessments in 2004 have not been updated, but in September 2010, the Minister for Water Affairs published regulations for the establishment of a classification system (RSA, 2010). ${ }^{56}$ These regulations are very important for the classification of water resources and the establishment of the Reserve. The regulations essentially provide for the procedures for the determination, progressively, of classes of water resources, the Reserve and resource water quality objectives. The regulations are relatively short (only 5 clauses) but they provide for a complex exercise involving substantial amounts of information. It is clear that the procedures detailed in the regulations will probably take some time and effort to get right (certainly if the implementation of the Act thus far is anything to go by). The task will involve the collection of significant amounts of data for the various catchments in the country, followed by evaluations on the basis of that data (for example, evaluating ecosystem goods and services). Following the procedure set out in the regulations is very important because it will determine, inter alia, the amount of water that can be allocated for use in various catchments, taking the Reserve into account.

This complex process is a central component of what can be called an integrated water resources management (IWRM) approach. Such an approach requires considerable understanding of the hydrological cycle. Commentators have identified challenges to the successful implementation of an IWRM approach in South Africa, ${ }^{57}$ including the major impediment of internal problems within the Department of Water Affairs, the primary implementers of the new approach. Such problems include human capacity constraints, inadequate acceptance of the IWRM concept in practice, 'insufficient cooperation between the different sectors and different policies that impact on water ${ }^{58}$ (for example, management of watercourses and management of land within the catchments are handled by different government departments), and that public participation in water decision-making is difficult due to capacity constraints particularly in rural areas.

Sight should also not be lost of the highly technical nature of the hydrological process in the process of determining the Reserve and water resource quality objectives in the different water management areas. It is critical for South Africa's future prosperity that the warning of Jewitt (2002) is heeded when it comes to the implementation of IWRM:

$[T]$ here is a danger that the rush to implement the new NWA in South Africa and the pressure applied by lobby groups, will once again lead to an oversimplification of the hydrological cycle. In particular, there is a danger that IWRM tools will be applied in such a way that that they will allow a level of degradation beyond that from which the ecosystem is able to recover i.e. beyond the level of its resilience. ${ }^{59}$

Conspicuous by its absence in many discussions about water management in South Africa has been the ecological component. In Mazibuko, for example, in not one of the three judgments did the Courts concerned consider the linkages between provision of water for human consumption and the reservation of sufficient water in the water resources that supplied the water in order to secure the vitality of the aquatic environment. In meeting the challenges in the water sector set out in this paper, this blind spot needs to be kept in mind.

\footnotetext{
${ }^{55}$ DWAF, above $\mathrm{n} 2$.

${ }^{56}$ RSA GN R810 in GG 33541 of 17 September 2010.

${ }^{57}$ N Funke, S H H Oelofse, J Hattingh, P J Ashton and A R Turton, 'IWRM in Developing Countries: Lessons from the Mhlatuze Catchment in South Africa' (2007) 32 Physics and Chemistry of the Earth 1237.

${ }^{58}$ Ibid 1244.

${ }^{59}$ Graham Jewitt, 'Can Integrated Water Resources Management Sustain the Provision of Ecosystem Goods and Services? (2002) 27 Physics and Chemistry of the Earth 887, 893.
} 


\section{Conclusion}

This analysis suggests that South Africa has, on paper, a legal system in respect of water management that can address the problems of both water quantity and quality identified in this paper on a prospective basis. Many of these problems, however, have been allowed to develop to such an extent that the law alone is not able to solve the problems. Political will has been identified as a major driver of improved water management and this will have to be transformed in order to ensure that the available legal machinery be used in the future to avoid similar problems arising again. As for the present problems, there are available legal mechanisms but they will have to be used in conjunction with political solutions accompanied by large amounts of money. The current problems of poisoned water, in other words, require both legal and political solutions.

South African water law is aimed ultimately at the achievement of integrated water resources management which, it could be argued, is essential to the achievement of sustainable water use in the country. Achievement of sustainable water use in South Africa would be difficult enough without having to deal with the numerous water problems identified in this paper - largely inherited from a past when applicable laws were not consistently or coherently applied. The fact that these problems have to be addressed makes the achievement of IWRM in South Africa considerably more difficult than it could have been and contributes significantly to the possibilities of conflicts arising in the water sector.

Keywords: South African water law, acid mine drainage, water shortage, environmental water 